\title{
Analysis of genetic variability, heritability and genetic advance for yield and yield associated traits in some promising advanced lines of rice
}

\author{
MA Islam ${ }^{1}$, SA Raffi ${ }^{2}$, MA Hossain ${ }^{2}$, AK Hasan ${ }^{1 *}$ \\ ${ }^{1}$ Department of Agronomy, ${ }^{2}$ Department of Genetics and Plant Breeding, Bangladesh Agricultural University, \\ Mymensingh 2202, Bangladesh.
}

\begin{abstract}
A field experiment was conducted using twenty three rice genotypes including three check varieties during the period from June to December, 2013, at the Agronomy Field Laboratory, Department of Agronomy, Bangladesh Agricultural University, Mymensingh to study genetic variability, heritability and genetic advance (GA) for yield and yield associated traits in rice. The experiment was laid down in a randomized complete block design with three replications. Plant height, number of filled grains per panicle, days to 50\% flowering, thousand grain weight, grain width and grain yield showed relatively high genotypic co-efficient of variation (GCV) and phenotypic co-efficient of variation (PCV) estimates. The PCV were higher than GCV for all eight traits indicating that they all interacted with the environment to some extent. High heritability was obtained for grain width (88.54\%), followed by days to 50\% flowering (87.61\%), thousand grain weight (81.96\%), grain length (81.94\%), days to maturity (81.81\%) and number of filled grains per panicle (78.19\%) which indicates high heritable portion of variation. High to medium estimates of heritability and genetic advance were obtained for number of filled grains per panicle (18.97), days to 50\% flowering (11.89), days to maturity (12.16) indicating the roles of additive gene action and a good scope of selection using their phenotypic performance. Considering, all of these characters, filled gains per panicle and days to $50 \%$ flowering and maturity were important yield related traits and could be used for selection in rice breeding programs.
\end{abstract}

Key words: Variability, broad sense heritability, genetic advance, rice

Progressive Agriculturists. All rights reserve

*Corresponding Author: ahmedbau@gmail.com

\section{Introduction}

Among the most cultivated cereals in the world, rice ranks as second to wheat (Abodolereza and Racionzer, 2009). Bangladesh is the fourth largest producer and consumer of rice in the world (FAO, 2011), with annual production of 25 million tons from 10.5 million hectares of land (BBS, 2013) where, the yearly requirement of rice in Bangladesh is 31 million tons (BBS, 2013). In order to meet the fast growing demand for rice, development of high yielding genotypes with desirable agronomic traits for diverse ecosystem is therefore a necessity. To increase its production a study of yield and its component characters viz. plant height, filled grain per panicle, days to $50 \%$ flowering and maturity, panicle length, 1000-grain weight and grain size i.e. grain length and width etc. are important and also essential fundamental task for making any successful breeding program (Xing and Zhang, 2010; Sakamoto et al., 2006). The yield component does not act independently and in general, they are interrelated with each other that ultimately bring about the grain yield in rice. Moreover, most of the yield component traits are quantitative in nature and the variability present in them is both heritable and non-heritable (Stuber, 1987). Thus, the knowledge of genetic variability present in a given crop species for the character under improvement is of paramount importance for the success of any plant breeding 
program (Hub, 2011). Heritability and genetic advance are important selection parameters while selection is made based on yield contributing traits. Heritability estimates along with genetic advance are normally more helpful in predicting the gain under selection than heritability estimates alone (Paul et al., 2006). Therefore, the objective of this study was to assess the genetic variability, heritability and genetic advance (GA) of yield and yield associated traits in some promising rice genotypes to assist the future breeding programs for yield improvement.

\section{Materials and Methods}

The experiment was conducted at the Agronomy Field Laboratory, Bangladesh Agricultural University (BAU), Mymensingh, during the period from July' 2013 to December' 2013.Twenty advanced lines (collected from GPB, BAU) and three check varieties viz. BR 11, BRRI dhan49, BRRI dhan57 were used in the present study (Table 1).

Table 1. The list of the genotypes used in the experiment with their sources

\begin{tabular}{|c|c|c|}
\hline Sl. No. & Pedigree & Source \\
\hline G1 & Hy-17-1062 & GPB, BAU \\
\hline G2 & Hy-1-6 & GPB, BAU \\
\hline G3 & Hy-1-38-38 & GPB, BAU \\
\hline G4 & Hy-3-277 & GPB, BAU \\
\hline G5 & Hy-1-69-69 & GPB, BAU \\
\hline G6 & Hy-2-75-247 & GPB, BAU \\
\hline G7 & Hy-6-161 & GPB, BAU \\
\hline G8 & Hy-9-728 & GPB, BAU \\
\hline G9 & Hy-9-786 & GPB, BAU \\
\hline G10 & Hy-10-28-597 & GPB, BAU \\
\hline G11 & Hy-12-262 & GPB, BAU \\
\hline G12 & Hy-11-845 & GPB, BAU \\
\hline
\end{tabular}

\begin{tabular}{|c|c|c|}
\hline Sl. No. & Pedigree & Source \\
\hline G13 & Hy-3-27-292 & GPB, BAU \\
\hline G14 & Hy-3-4-269 & GPB, BAU \\
\hline G15 & Hy-4-24-353 & GPB, BAU \\
\hline G16 & Hy-14-849 & GPB, BAU \\
\hline G17 & Hy-2-234 & GPB, BAU \\
\hline G18 & Hy-9-62-737 & GPB, BAU \\
\hline G19 & Hy-15-861 & GPB, BAU \\
\hline G20 & Hy-16-1201 & GPB, BAU \\
\hline G21 & BRRI dhan 57 & BRRI, Gazipur \\
\hline G22 & BRRI dhan 49 & BRRI, Gazipur \\
\hline G23 & BR 11 & BRRI, Gazipur \\
\hline
\end{tabular}

Note: GPB= Department of Genetics and Plant Breeding, BAU= Bangladesh Agricultural University, BRRI= Bangladesh Rice Research Institute, Hy= Hybrid

The experiment was laid out in a randomized complete block design (RCBD) with three replications. Each replication was consisted of twenty three plots and each of the plot was $5.0 \mathrm{~m}^{2}$. The pre-germinated seeds were sown in seedbed on $14^{\text {th }}$ July 2013. One seedling per hill was transplanted to the main plot on the $04^{\text {th }}$ August, 2013 when they were 21 days old. Row to row and plant to plant distance were $20 \mathrm{~cm}$ and $15 \mathrm{~cm}$, respectively. Fertilizers were applied at the rate of Urea $170 \mathrm{~kg}$, TSP 70kg, MP 100kg, Zypsum 80kg and Cowdung 2 tons/ha. Gap filling was done within seven days after transplanting with the seedlings from the same sources to obtain uniform plant population. Irrigation, drainage, and weeding were done as and when required. Ten sample plants were randomly chosen from each plot for recording observations on some morpho-physiological traits viz. plant height (cm), filled grain per panicle, days to $50 \%$ flowering, days to maturity, grain length $(\mathrm{mm})$, grain width (mm), thousand grain weight (g) and grain yield (t/ha). Genotypic and phenotypic variances were estimated according to the formula given by (Johnson et al. 1955). Genotypic and phenotypic coefficient of variations were estimated according to (Burton, 1952) and (Singh and Chaudhary, 1985). Heritability in broad sense $\left(\mathrm{h}^{2}{ }_{\mathrm{b}}\right)$ was estimated according to the formula suggested by (Johnson et al,. 1955) and (Hanson et al., 1956). Estimation of genetic advance was done following the formula given by (Johnson et al., 1955) and (Allard, 1960). 


\section{Results and Discussion}

Genotypic variances, phenotypic variances, heritability, genotypic co-efficient of variation (GCV), phenotypic co-efficient of variation (PCV), genetic advance and genetic advance as percent of mean, GA (\%) for all the yield contributing traits are presented in Table 2.

\section{Estimation of variability parameters}

A wide range of variation was observed among twenty three rice genotypes for seven yield contributing traits and yield as well. The perusal of ANOVA revealed that variance for all traits was highly significant (not presented). This suggested that there were inherent genetic differences among the genotypes. Phenotypic variance was higher than the genotypic variances for all the traits thus indicated the influences of environmental factor on these traits. Similar findings were reported earlier by Devi et al. (2006) and Prajapati et al. (2011). Coefficient of variation studied indicated that estimates of phenotypic coefficient of variation (PCV) were higher than the corresponding genotypic coefficient of variation (GCV) for all the traits (Table 2) indicating that they all interacted with the environment to some extent. Bhadru et al. (2012) also mentioned the same result in rice. The estimates of genotypic coefficient of variation (GCV) was $5.75 \%$ in plant height, $7.27 \%$ in days to $50 \%$ flowering, $6.08 \%$ in days to maturity, $12.27 \%$ in filled grain per panicle, $8.03 \%$ in 1000 grain weight, $5.75 \%$ in grain length, $8.12 \%$ in grain width and $22.13 \%$ in grain yield. The higher estimate of phenotypic coefficient of variation (PCV) was obtained for all the characters corresponding to GCV. In this regards, Sawant et al. (1994) reported high GCV and PCV for grains per panicle, plant height, 1000 grain weight and grain yield per plant; Singh and Choudhary (1996) for number of panicle per plant, number of grains per panicle, grain yield per plant and 1000 grain weight; Sarkar et al. (2005) for number of panicle per plant, number of tiller per plant and grain yield per plant; Raut et al. (2009) for seed yield per plant, 1000 grain weight, grains per panicle and effective tiller per plant; Anjaneyulu et al. (2010) for number of grain per panicle, fertility per cent and grain yield per plant and Kumar and
Senapati (2013) for grain yield per plant, panicle weight, number of panicles per plant, number of secondary branches per panicle, number of grains per panicle, 1000 grain weight and florets number per panicle.

\section{Estimation of Heritability}

The estimates of heritability act as predictive instrument in expressing the reliability of phenotypic value. Therefore, high heritability helps in effective selection for a particular trait. Heritability was classified as low (below 30\%), medium (30-60\%) and high (above 60\%) as suggested by Johnson et al. (1955). The traits studied in the present investigation expressed moderate to high heritability estimates ranging from 35.02 to 88.54 percent. Among the traits, high heritability was observed for days to $50 \%$ flowering, days to maturity, filled grain per panicle, 1000 grain weight, grain length, grain width and yield per hectare (Table 2). Similar results were earlier reported by Bihari et al. (2004) for days to 50 per cent flowering and test weight; Sankar et al. (2006) for days to 50 per cent flowering, plant height, panicle length, grains per panicle and test weight and Karthikeyan et al. (2009) for days to 50 per cent flowering and 1000 grain weight. The plant height was observed to possess lowest heritability (35.03\%), however, in a previous study, Patel et al. (2012) found higher heritability for plant height. High heritability values indicate that the traits under study are less influenced by environment in their expression. The plant breeder, therefore, may make his selection safely on the basis of phenotypic expression of these traits in the individual plant by adopting simple selection methods.

\section{Genetic advance}

The genetic advance is a useful indicator of the progress that can be expected as result of exercising selection on the pertinent population. Heritability in conjunction with genetic advance would give a more reliable index of selection value (Johnson et al., 1955). Filled grain per panicle recorded the highest GA followed by days to maturity, days to $50 \%$ flowering, plant height. These findings were in agreement with that of Amirthadevathinam (1990) for grains per panicle; Lokaprakash et al. (1992) for 1000 -seed weight and number of fertile spikelets per 
panicle and Sarma et al. (1996) for number of secondary branches per panicle. The lowest GA was observed in grain width, followed by grain length and yield per hectare. The estimates of genetic advance as percent of mean were highest for yield per hectare, followed by grain width, filled grain per panicle,1000-grain weight, days to $50 \%$ flowering, grain length and days to maturity. These findings were earlier corroborated by different workers for one or more characters e.g. Chaubey and Singh (1994) for grain yield per plant, panicle weight and total number of spikelets; Sarma et al. (1996) for effective tillers/m row length and panicle weight; Karthikeyan et al. (2009) for number of branches per panicle, straw yield per plant, total biological yield per plant and grain yield per plant; Kumar and Senapati (2013) for grain yield per plant. The lowest GA as percentage of mean was observed in plant height. High heritability coupled with high genetic advance was obtained for filled grain per panicle, days to 50 percent flowering and days to maturity. These findings were corroborated by Singh et al. (2005) for plant height; Sanker et al. (2006) for days to 50 per cent flowering, plant height, productive tiller per plant, panicle length, grain per panicle,
1000 seed weight and single plant yield; Singh et al. (2007) for days to 50 percent flowering and grain per panicle; Kishore et al. (2008) for days to 50 per cent flowering, plant height, water uptake and gel consistency; Sabesan et al. (2009) for grain yield per plant, 100 grain weight, productive tillers per plant, grains per panicle, grain length, grain breadth, kernel length, panicle length and plant height; Pal et al. (2011) for grain/panicle, and days to 50\% flowering. Hence it indicated the predominance of additive gene action for controlling these characters. Therefore, these characters can be improved simply through selection. High heritability with low genetic advance was observed for grain width, grain length and grain yield. It suggested non-additive gene action for the expressions of these characters. The high heritability was exhibited due to favorable influence of environment rather than genotype and selection for such traits might not be rewarding. Low heritability coupled with high genetic advance was registered for plant height. It revealed that the character is governed by additive gene effects. The low heritability was being exhibited due to high environmental effects. Therefore, selection for this character might be effective.

Table 2. Estimation of genetic parameters of twenty three rice genotypes based on yield contributing traits

\begin{tabular}{|r|l|c|c|c|c|c|c|c|}
\hline $\begin{array}{r}\text { SL. } \\
\text { No. }\end{array}$ & \multicolumn{1}{|c|}{ Traits } & $\begin{array}{c}\text { Phenotypic } \\
\text { Variance } \\
\left(\delta^{2} \mathrm{p}\right)\end{array}$ & $\begin{array}{c}\text { Genotypic } \\
\text { Variance } \\
\left(\delta^{2} \mathrm{~g}\right)\end{array}$ & PCV (\%) & GCV (\%) & $\begin{array}{c}\text { Heritability } \\
(\%)\end{array}$ & GA & GA (\%) \\
\hline 1 & Plant height (cm) & 85.83 & 30.06 & 9.72 & 5.75 & 35.02 & 6.68 & 7.01 \\
\hline 2 & $\begin{array}{l}\text { Filled grain per } \\
\text { panicle }\end{array}$ & 581.57 & 222.08 & 19.86 & 12.27 & 78.19 & 18.97 & 15.62 \\
\hline 3 & $\begin{array}{l}\text { Days to 50\% } \\
\text { flowering }\end{array}$ & 43.40 & 38.02 & 7.76 & 7.27 & 87.61 & 11.89 & 14.01 \\
\hline 4 & Days to maturity & 52.03 & 42.57 & 6.08 & 5.50 & 81.81 & 12.16 & 10.25 \\
\hline 5 & $\begin{array}{l}\text { 1000 grain weight } \\
\text { (g) }\end{array}$ & 3.81 & 3.12 & 8.87 & 8.03 & 81.96 & 3.29 & 14.98 \\
\hline 6 & Grain length (mm) & 0.31 & 0.25 & 6.36 & 5.75 & 81.94 & 0.94 & 10.73 \\
\hline 7 & Grain width (mm) & 0.05 & 0.05 & 8.63 & 8.12 & 88.54 & 0.42 & 15.73 \\
\hline 8 & Yield (t ha ${ }^{-1}$ ) & 1.02 & 0.64 & 27.94 & 22.13 & 62.76 & 1.30 & 36.12 \\
\hline
\end{tabular}

Note: PCV= Phenotypic coefficient of variation, GCV= Genotypic coefficient of variation, GA= Genetic advance, GA (\%) = Genetic advance as percent of mean

\section{Conclusion}

The characters filled grain per panicle, days to maturity, days to $50 \%$ flowering, plant height are attributable to additive gene effects which indicating that improvement in these characters is possible through hybridization followed by selection with pedigree breeding. The characters grain width, grain 
length with high heritability with low genetic advance indicating the character is influenced by environmental effects and selection may not be useful.

\section{References}

Abodolereza A, Racionzer P (2009). Food Outlook: Global market analysis. 23-27. Available:www.fao.org/docrep/012/ak341f/ ak341f00.

Allard RW (1960). Principles of Plant Breeding.mJohn Wiley and Sons. Inc., New York Anbanandan, V., Saravanan, K. and Sabesan, T. 2009. Variability heritability and genetic advance in rice.m(Oryzasativa L.). Int. J. Plant Sci., 3(2): 61-63.

Amirthadevarathinam A (1990). Genetic variability, interrelationship and path analysis of yield and yield characters in early maturing indica and japonica rice genotypes. Madras Agric. J., 77: 363-68.

Anjaneyulu M, Reddy DR, Reddy KHP (2010). Genetic variability, heritability and genetic advance in rice (Oryza sativa L.). Res. Crops, 11: 415-16.

BBS (2013). The year book of agricultural statistics of Bangladesh. Stat. Div. Ministry. Plan., Govt. Peoples Rep. Bangladesh. Dhaka, pp.123-127.

Bhadru D, Rao VT, Mohan YC Bharathi D (2012). Genetic variability and diversity studies in yield and its component traits in rice (Oryza sativa L.). SABRAO J. Breed. Genet., 44(1): 129-137.

Bihari PK, Richharia AK, Sahu RS (2004). Genetic advance for yield attributes in aromatic rice. J. Appl. Biol., 14: 1-5.

Burton GW (1952). Quantitative inheritance in Grasses.Proc. 6Th Intl. Grassld.Congr., 1: 7283.

Chaubey PK, Singh RP (1994). Genetic variability, correlation and path analysis of yield components of rice. Madras Agric. J., 81: 468-70.

Devi SL, Raina FA, Pandey MK, Cole CR (2006). Genetic parameters of variation for grain yield and its components in rice. Crop Res., 32 (1): 69-71.
FAO (2011). Food and agricultural commodities production. Food and Agriculture Organization of the United Nations.

Hanson G, Robinson HF, Comstock RE (1956). Biometrical studies on yield in segregating population of Korean Lespedeza. Agron. J., 48:268-274.

Hub B (2011). Definition and Significance of Genetic Variability, Crop Res., 32 (1): 6971.

Johnson HW, Robinson HF, Comstock RE (1955). Estimates of genetic and environmental variability in soybean.Agron. J., 47: 314318

Johnson HW, Robinson HF, Comstock RE (1955). Estimates of genetic and environmental variability in soybean.Agron. J., 47: 314318

Karthikeyan P, Anbuselvam Y, Elangaimannan R, Venkatesan M (2009). Variability and heritability studies in rice (Oryza sativa L.) under coastal salinity. Electronic J. Pl. Breed., 1: 196-98.

Kishore NS, Babu VR, Ansari NA, Prasad AR (2008). Genetic variability, heritability and genetic advance in rice (Oryza sativa L.) genotypes of different ecogeographical regions. Res. Crops, 9: 147-50.

Kumar A, Senapati BK (2013). Genetic parameters and association studies for important quantitative traits in advanced lines of Sambamahsuri derivatives. J. Crop Weed, 9:156-63.

Lokaprakash R, Shivashankar G, Mahadevappa M, Gowda BTS, Kulkarni RS (1992). Study on genetic variability, heritability and genetic advance in rice. Indian $\mathrm{J}$ Genet. $\mathrm{Pl}$. Breed., 52: 416-21.

Pal G, Verma OP, Verma GP, Pratap N, Chaudhary MKRK, Singh K (2011). Genetic variability, heritability and divergence studies in rice (Oryza sativaL.) under sodic soil, Env. Eco., 29: 1597-1600.

Patel A, Chaudhari PR, Verulkar SB (2012). Analysis of genetic variability, heritability and genetic advance for yield and yield components in rice (Oryza sativa L.) under 


\section{Genetic variability, heritability and genetic advance of rice}

different water regimes. Plant Archives, 12(1): 425-435.

Paul AKMA, Islam MJ, Hasan MMH, Chowdhury, AZMKA (2006). Genetic variation of some morpho-physiological characters in Triticum durum wheat. Int.J.Sustain. Agric. Tech., 2(8): 11-14.

Prajapati M, Singh CM, Suresh BG, Lavanya GR, Jadhav P (2011). Genetic parameters for grain yield and its component characters in rice. Elec. J. Pl. Breed., 2(2): 235-238.

Raut KR, Harer PN, Yadav PS (2009). Genetic variability and character association in rice (Oryza sativa L.). J. Maharashtra Agric. Univ., 34: 174-78.

Sabesan T, Suresh R, Saravanan K (2009). Genetic variability and correlation for yield and grain quality characters of rice grown in coastal saline low land of Tamilnadu. Electronic J. Pl. Breed., 1: 56-59.

Sakamoto T, Morinaka Y, Ohnishi T, Sunohara H, Fujioka S, Ueguchi-Tanaka M, Mizutani M, Sakata K, Takatsuto S, Yoshida S, Tanaka H, Kitano H, Matsuoka M (2006). Erect leaves caused by brassinosteroid deficiency increase biomass production and grain yield in rice. Nat Biotechnol 24: 105-109

Sankar PD, Sheeba A, Anbumalarmathi J (2006). Variability and character association of cultivars of rice (Oryza sativa L.). Agric. Sci. Digest, 26: 182-84.

Sarkar KK, Bhutia KS, Senapati BK, Roy SK, Panda S, Mondal AB (2005). Genetic variability and relationships between grain yield and its component traits in rice (Oryza sativaL.). Env. Eco., 23 : 702-706.
Sarma MK, Richharia AK, Agarwal RK (1996). Variability, heritability, genetic advance, and genetic divergenc in upland rice. Int. Rice Res. Notes, 21: 25-26.

Sawant DS, Patil SL, Bhave SG (1994). Variability, heritability and genetic advance in pure lines of lowland rice Annals Agric. Res., 15: 27-30.

Singh RK, Choudhury BD (1985). Biometrical method in quantitative genetic analysis. Kalyani Publishers, Ludhiana, New Delhi, pp. 54-57.

Singh RP, Kumar MS, Madhavilatha L (2007). Variability and relationship studies of yield and yield attributing traits in diverse lines of international irrigated observational nursery of rice (Oryza sativa L.). J. Res. ANGRAU, 35: 16-22.

Singh S, Choudhary BS (1996). Variability, heritability and genetic advance of rice (Oryza sativa L.). Crop Res. Hisar, 12: 16567.

Singh SP, Singhara GS, Parray GA, Bhat GN, (2005). Genetic variability and heritability in rice (Oryza sativa L). Env. Eco., 23 : 549-51.

Stuber CW, MD, Edwards (1987). Molecular Marker-Facilitated Investigations of Quantitative Trait Loci in Maize. II. Factors Influencing Yield and its Component Traits. Crop Sci. 27(4): 639-648.

Xing Y, Zhang Q (2010). Genetic and molecular bases of yield. Annu Rev Plant Biol 61: 421-441 